Journal of Maternal and Child Health (2016), 1(3): 138-145

https://doi.org/10.26911/thejmch.2016.01.03.01

\title{
Effect of Psychological Factors and Workload on Midwife Performance in the Integrated Antenatal Care In Pati, Central Java
}

\author{
Siti Marfu'ah'), Didik Tamtomo²), Arief Suryono3) \\ 1)Academy of Midwifery Bakti Utama, Pati, Central Java \\ ${ }^{2)}$ Faculty of Medicine, Universitas Sebelas Maret \\ 3)Faculty of Law, Universitas Sebelas Maret
}

\begin{abstract}
Background: One of the sensitive population health indicators is maternal mortality rate (MMR).One of the MMR determinants is antenatal care (ANC) coverage. This study aimed to determine the effect of psychological factors and workload on midwife work performance in the integrated antenatal care in Pati, Central Java.

Subjects and Method: This was analytic observational study with cross sectional design. This study was conducted in Pati, Central Java. A total of 130 midwives was selected for this study by stratified random sampling. The dependent variable was work performance. The independent variables were motivation, self eficacy, self actualization, workload, and midwife peer group as the contextual variable. The data were collected by a set of questionnaire. The data were analyze by linear multilevel multiple regression model.

Results: Motivation $(\mathrm{b}=0.15 ; 95 \% \mathrm{CI}=0.01$ to $0.29 ; \mathrm{p}=0.035)$, self actualization $(\mathrm{b}=0.21 ; 95 \%$ $\mathrm{CI}=-0.01$ to $0.40 ; \mathrm{p}=0.031)$, and self efficacy $(\mathrm{b}=0.15 ; 95 \% \mathrm{CI}=-0.01$ to $0.31 ; \mathrm{p}=0.048)$ had positive and statistically significant effects on work performance. Workload $(b=-0.26 ; 95 \% \mathrm{CI}=-0.53$ to $0.01 ; p=0.056$ ) had negative and nearly significant effect on work performance. There was a contextual effect of midwife group on work performance. $I C C=17.51 \%$; likelihood ratio $=-262.55$; $\mathrm{p}=0.006$.

Conclusion: Motivation, self actualization, and self efficacy have positive effects on work performance. Workload has negative effect on work performance. Midwife group has a contextual effect on work performance.
\end{abstract}

Keywords: psychological factors, workload, work performance, midwife.

\section{Correspondence:}

SitiMarfuah. Academy of Midwifery BaktiUtama, Pati, Central Java.

Email: sty_marfuah@yahoo.com. Mobile: o85729885380

\section{BACKGROUND}

Development of the health sector is a very important part in the effort to improve the quality of Human Resources (HR). Maternal and child health problems are a national problem that needs to get top priority to be solved because it is one indicators of the health status of a nation. Health development is a part of development that aims to increase the awareness and ability to live healthy for everyone in order to achieve the highest level of public health.
One indicator of the high level of health of a nation is the coverage of the Maternal Mortality Rate (MMR). The high MMR in Indonesia makes the government put some efforts to reduce MMR as a priority program in health development. Indonesia's Demographic Health Survey shows that the 2014 maternal mortality rate in Indonesia was 126 per 100,000 live births, while the 2015 Millennium Development Goals target was 102 / 100,000 live births. This is a problem of course in the field of health, so the question arises as to 
why these goals have not yet been achieved (Ministry of Health, 2014).

Maternal Mortality Rate (MMR) in Central Java Province in 2013 reached 118 per 100,000 live births. In 2014, it was 126 per 100,000 live births and in 2015, it was 111 per 100,000 live births. In Pati District, maternal mortality in 2013 was 167 per 100,000 live births, in 2014, it was 95 per 100,000 live births and in 2015 was 117 per 100,000 live births. The cause of maternal mortality in Pati regency was preeclampsia and bleeding (Pati District Health Office, 2016).

One of the efforts to reduce maternal mortality is Antenatal Care (ANC) services. According to Pusdiknakes (2003) cited by Endang (2011), midwifery services by midwives at the puskesmas were antenatal examinations, namely a prenatal check up to check the condition of the mother and fetus at regular intervals, followed by corrections to irregularities found.

The main purpose of antenatal care is to facilitate healthy and positive outcomes for both the mother and her baby by building a relationship of mutual trust with the mother, detecting complications that can be life threatening, preparing for birth and providing education. Antenatal care is important to ensure that the natural process continues normally during pregnancy.

Quantitatively, the 2015 Pati Regency Antenatal Care (ANC) target coverage data is close to the target set, that is, pregnant women (100\%) have examined the first pregnancy pregnancy $(\mathrm{K}-1)$, pregnant women (96.03\%) have already visited K-4 with a frequency of at least 4 times during pregnancy. The coverage of labor by Pati health personnel is $98.29 \%$ (Pati District Health Office, 2016).

Various efforts have been carried out by Pati District Health Office to improve the performance of midwives, including by increasing the education level of village midwives to Diploma III Midwifery Maternal Perinatal Audit (AMP) training, IUD insertion training, Normal Childbirth Care (APN) training, and Obstetrics Handling training and Neonatal Basic (SBD Health Office, 2015). However, these efforts have not produced good midwife performance results. Quantitatively, K-1 and K-4 coverage in Pati regency is in accordance with the target set of $100 \%$ and $98 \%$ but the high maternal mortality rate in Pati Regency is related to the problem of midwife's performance in providing services that are considered as not optimal (Pati District Health Office, 2016).

Performance is the output produced by functions or indicators of a job within a certain time. Performance is a function of competence, attitude and action. If the competencies, attitudes and actions of employees towards their work are high, then it can be predicted that they will work hard to achieve organizational goals (Gibson, 2001).

According to Gibson (2001), there are three variables that affect behavior and performance, namely individual variables (ability and expertise, background and demography), psychological variables (perception, attitude, learning and motivation) and organizational variables (resources, leadership, rewards/rewards, structure, design, and work).

The three groups of variables influence work behavior which ultimately affects personal performance. Performance-related behavior is related to work tasks that must be completed to achieve the goals of a position or task (Gibson, 2001).

Research on the influence of psychological factors and workload is necessary to conduct. This aims to determine the influence of psychological factors and workload 
Journal of Maternal and Child Health (2016), 1(3): 138-145

https://doi.org/10.26911/thejmch.2016.01.03.01

on the performance of midwives in providing Integrated Antenatal Care Services in Pati, Central Java.

\section{SUBJECTS AND METHOD \\ 1. Study Design \\ This was a cross sectional study conducted in Pati, Central Java, from September to October 2016. A sample of 130 patients was selected for this study to assess midwife performance.}

\section{Study Variables}

The dependent variable was work performance. The independent variables weer motivation, self eficacy, self actualization, workload, and midwife peer group as the contextual variable.

\section{Data Collection}

The data were collected by a set of questionnaire and analyzed by a linear multilevel multiple regression.

\section{$\frac{\text { RESULTS }}{\text { 1. Univariate analysis }}$}

Table 1 shows the study subjects characteristics. Table 1 shows that as many as $57 \%$ midwives had good performance, $65 \%$ had high work motivation, and $62 \%$ had good self-efficacy.

\begin{tabular}{lcc}
$\begin{array}{l}\text { Table } \\
\text { characteristics }\end{array}$ & Study & subjects \\
\hline \multicolumn{1}{c}{ Variable } & n & \% \\
\hline $\begin{array}{l}\text { Workload } \\
\text { a. Light }\end{array}$ & 18 & $69 \%$ \\
$\begin{array}{l}\text { b. Heavy } \\
\text { Self-Efficacy }\end{array}$ & 8 & $31 \%$ \\
$\begin{array}{l}\text { a. Poor } \\
\text { b. Good }\end{array}$ & 10 & $38 \%$ \\
$\begin{array}{l}\text { Self-Actualization } \\
\text { a. Low }\end{array}$ & 16 & $62 \%$ \\
$\begin{array}{l}\text { b. High } \\
\text { Motivation }\end{array}$ & 8 & $31 \%$ \\
$\begin{array}{l}\text { a. Low } \\
\text { b. High }\end{array}$ & 18 & $69 \%$ \\
$\begin{array}{l}\text { The performance of } \\
\text { midwives }\end{array}$ & 9 & $35 \%$ \\
a. Poor & 17 & $65 \%$ \\
b. Good & & \\
\hline
\end{tabular}

\section{Bivariate analysis}

Table 2 shows the effect of workload, selfefficacy, self-actualization and motivation on the performance of midwives in providing integrated antenatal care services. Table 2 shows that there is a negative effect between workload on midwife performance and statistically significant. Midwives who have a low workload in carrying out service duties and responsebilities are more likely to have good performance than midwives who have a heavy workload $(b=-0.26 ; 95 \%$ $\mathrm{CI}=-0.53$ to $0.01 ; \mathrm{p}=0.056$ ).

Table 2. Effect of workload, self-efficacy, self-actualization and motivation on the performance of midwives in providing integrated antenatal care service

\begin{tabular}{|c|c|c|c|c|}
\hline \multirow{2}{*}{ Independent Variable } & \multirow{2}{*}{ B } & \multicolumn{2}{|c|}{$95 \%$ CI } & \multirow[b]{2}{*}{$\mathbf{p}$} \\
\hline & & Lower limit & Upper limit & \\
\hline \multicolumn{5}{|l|}{ Fixed effect } \\
\hline Workload & -0.26 & -0.53 & 0.01 & 0.056 \\
\hline Self-Efficacy & 0.15 & 0.01 & 0.31 & 0.048 \\
\hline Self-Actualization & 0.21 & 0.01 & 0.40 & 0.031 \\
\hline Motivation & 0.15 & 0.01 & 0.29 & 0.035 \\
\hline \multicolumn{5}{|l|}{ Random effect } \\
\hline \multicolumn{5}{|l|}{ Midwife } \\
\hline Var (kons) & & 0.20 & 1.80 & \\
\hline \multicolumn{5}{|l|}{$\mathrm{ICC}=17.51 \%$} \\
\hline Likelihood Ratio Test $\mathrm{p}=-\mathbf{2 6 2 . 5 5}$ & & & & \\
\hline
\end{tabular}

There is a positive influence between selfefficacy in working towards the performance of midwives and it is statistically significant. Midwives who have good selfefficacy in carrying out service duties and responsibilities are more likely to have good 
performance than midwives who have poor self-efficacy ( $b=0.15 ; 95 \% \mathrm{CI}=0.01$ to 0.31 ; $\mathrm{p}=0.048$ ).

There is a positive influence between self-actualization in working on the performance of midwives and statistically close to significant. Midwives who have good self-efficacy in carrying out service duties and responsibilities are more likely to have good performance than midwives who have poor self-efficacy $(b=0.21 ; 95 \% \mathrm{CI}=0.01$ to $0.40 ; p=0.031)$.

There is a positive influence between motivation in working on the performance of midwives and is statistically close to significant. Midwives who have high motivation in carrying out service duties and responsibilities are more likely to have good performance than midwives who have low motivation ( $b=0.15 ; 95 \% \mathrm{CI}=0.01$ to 0.29 ; $\mathrm{p}=0.035$ ).

\section{DISCUSSIONS}

The result of this study showed that there was a negative effect of workload on midwife performance and it was statistically significant. The midwives who have low workload in carrying out their duty and responsibility services were more likely to have good performance than midwives who have heavy workload.

According to Lang et al., (2004) in Carayon (2008), high nursing workload could affect patients safety, which mean the higher the workload of the nurse, the lower the patients safety. This was in accordance with the result of a study which stated that the higher the midwife's workload, the lower the work performance.

The undesirable thing was the impact of high workload. If the workload received was too heavy, it could lead to work stress that can affect work motivation and decreased the performance (Hombergh et al., 2009 in Mudayana, 2012).
According to Gurses (2008) in Mudayana (2012), it was stated that workload could affect the employees' stress of work and it could also affect patients service and safety so that the midwife performance became low.The high workload of midwives was shown by the multiple duty carried out by midwives, for example, in addition to implementing integrated antenatal care services and other midwifery services, the midwives have other responsibilities such as responsibilities as a midwife in the village and as an administrative officer.

Midwifes who have high workload and good performance could feel the impact in the future, because the endurance of the human body would not survive for such a long time, and there would definitely be a decrease in endurance. Excessive workload would lead to various effects, namely physical and mental fatigue and emotional reactions such as headaches, digestive disorders, forgetfulness, and irritability so that it potentially endanger the workers (Manuaba, 2000).

The result of this study showed that there was a positive effect of self efficacy in working on midwife performance and it was statistically significant. The midwives who have good self efficacy incarrying out their duty and responsibility services were more likely to have good performance than midwives who have poor self efficacy $(b=$ $0.15 ; 95 \% \mathrm{CI}=0.01$ to $0.31 ; \mathrm{p}=0.048)$.

Baron and Byrne, 1991 as cited by Reni (2013) stated that self-efficacy was an evaluation of one's ability or competence to perform a task, achieve a goal, and overcome obstacles. Self-efficacy in a person was influenced by the individual's observation of something that happened in his/her social environment.

Individuals would improve their quality if they believed in their potential. Self-efficacy was certainly affected by 
Journal of Maternal and Child Health (2016), 1(3): 138-145

https://doi.org/10.26911/thejmch.2016.01.03.01

various factors. The role of peers, family, and educational institutions were also needed in increasing individuals' selfefficacy.

Self-efficacy affected the motivation, either when the manager provided rewards and when the employees provided their abilities. The higher the self-efficacy, the greater the motivation and performance. According to Cherrington (1994), self-efficacy was defined as a person's belief in his/her ability to do a specific task.

He admitted that in some ways, the concept of self-efficacy was similar to selfesteem and locus of control. However, selfefficacy was related to specific tasks compared to the general perception of overall competence.

Bandura in Luthan (2005) stated that expectations determine the behavior or performance, therefore, expectations were very decisive in contributing to behavior and also determined whether a behavior could be mantained in facing a problem or not.

Individuals who have low expectations of self-efficacy would affect their low behavior. In this context, the unavailability of self-efficacy expectations would lead to low participation and people chose to give up when facing the difficulties (Brown, 2001).

Confidence in one's own ability affected personal motivation, the higher the selfefficacy, the lower the level of stress. Conversely, the higher the confidence in one's own abilities, the more determined he/she would be to finish the task well. Confidence in efficacy affected the level of challenge in completing the tasks. It was not only the work skills that determine the success of the task implementation, but also determined by the level of confidence in the ability so that it could increase the intensity of motivation and employee's persistence to work.

The result of this study showed that there was a positive effect of self-actualization in working on midwife performance and it was statistically significant. The midwives who have good self-actualization incarrying out their duty and responsibility services were more likely to have good performance than midwives who have poor self-actualization $(b=0.21 ; 95 \% \mathrm{CI}=0.01$ to $0.40 ; \mathrm{p}=0.031$ ).

This was in line with a study done by Bambang (2015) which revealed that there was a significant effect of self-actualization onemployees work performance in the company activities of infrastructure conservation of large water resources in Brantas River area, Kediri.

The result of this study was also strengthened by Maslow in Arianto (2009) who stated thatself-actualization was the process of being ourself and developing unique psychological traits and potentials. From this understanding, it could be concluded that self-actualization was very necessary for employees because the maturity of thinking would allow people to put themselves according to their potential.

A study by Adhani (2013) showed a direct effect of self-actualization needs variable of employee performance which were shown by an employee who can actualize him/herself in the workplace, the employee would be dynamic, think positively, have high creativity, and want to do extra effort to optimize his/her ability so that it could produce an optimal productivity.

The need for self-actualization was the highest level of needs from Maslow's theory. When a person has fulfilled the four needs before him/her, he/she would need self-actualization needs where he/she was recognized as someone who has the influ- 
ence in a company. If these needs can be provided by the company, the employee's work performance would increase and provide benefits to the company.

The result of this study showed that there was a positive effect of work motivation on midwife performance and it was statistically significant. The midwives who have high motivation incarrying out their duty and responsibility services were more likely to have good performance than midwives who have low motivation $(b=0.15$; 95\% $\mathrm{CI}=0.01$ to $0.29 ; \mathrm{p}=0.035$ ).

This study was in accordance Istyarti and Wiwik (2008) which stated that the symptoms of motivation in the employee became a benchmark for his/her working conditions and this was in accordance with Mangkunegara (2006) which stated that those who have low work motivation would have low performance. In this case, the performance of midwives was assessed from integrated Antenatal Care (ANC) services.

With regard to low motivation among midwives, this study used a theory of Maslow, which stated that physiological needs, security needs, social needs, selfesteem needs, and self-actualization needs that could affect work motivation should also be understood by the head of the community health center to be the basis for improving midwife's work motivation, thus improving the performance of midwives in the implementation of integrated antenatal care (ANC) which could be done with more attention to these basic needs.

Low midwives motivation could lead to a lack of midwives adherence in providing integrated antenatal care (ANC) services which were standardized so that it would affect work targets in maternal and child health programs at health centers.

Work motivation was one of the factors that contribute to one's perform- ance. The effect of motivation on performance depend on how much the intensity of the motivation. The difference of work motivation for the officers was usually showed in various activities and their achievements (Hamzah, 2008).

This study concluded that there was an effect of psychological factors (selfefficacy, self-actualization, and motivation) and workload on the performance of midwives in providing integrated antenatal care services in Pati Regency. Theoretical implycations of this study were in accordance with Gibson's (2000) theory which stated that one of the variables that affect the performance was a psychological variable. From the results of this study, it was expected that the health office and the head of the health centers were able to improve the midwives performance through a psychological approach.

\section{REFERENCES}

Adiputri A (2014). Hubungan kompetensi, kompensasi financial dan supervise dengan kinerja bidan desa di Kabupaten Bangli. Tesis. Denpasar: Universitas Udanaya, Denpasar.

Arianto (2009). Psikologi umum. Jakarta: PT. Prenhalindo.

Cahyono B (2015). Pengaruh aktualisasi diri, penghargaan dan lingkungan kerja terhadap prestasi kerja karyawan pada kegiatan prasarana konservasi sumber daya air balai besar wilayah sungai brantas Kediri tahun 2015. Skripsi. Kediri: Universitas Nusantara PGRI Kediri.

Dinas Kesehatan Kabupaten Pati (2015). Profil kesehatan kabupaten Pati.

Dinas Provinsi Jawa Tengah (2015). Profil kesehatan Provinsi Jawa Tengah. Jawa Tengah.

Edy S (2012). Manajemen sumber daya manusia. Jakarta: Kencana. 
Endang R (2011). Evaluasi kinerja bidan puskesmas dalam pelayanan antenatal care (ANC) Di Kecamatan Banjarsari, Kota Surakarta. Tesis. Surakarta: Universitas Sebelas Maret.

Ertiana D (2016). Path analysis faktorfaktor yang berhubungan dengan dismenore. Tesis. Surakarta: Universitas Sebelas Maret.

Gibson J (2001). Organisasi dan manajemen perilaku struktur proses. Jakarta.

Handoko TH (2000). Manajemen personalia dan sumberdaya manusia edisi III. Yogyakarta: BPFE.

Ilyas Y (2001). Kinerja, teori, penilaian dan penelitian, cetakan ke-2, Jakarta: Pusat Kajian Ekonomi Kesehatan FKM-Universitas Indonesia.

Imran R (2012). How to boost employee performance: investigating the influence of transformational leader-ship and work environment in a pakistani perspective. Middle-East journal of scientific research.11(10): 1455-1462.

Iskandar M (2014). Factors influencing employees' performance: a study on the islamic banks in indonesia. International journal of business and social science, $5(2)$.

Ivancevich JM (2007). Perilaku \& manajemen organisasi. Erlangga: Jakarta.

Jayaweera T (2015). Impact of work environmental factors on job performance, mediating role of work motivation: a study of hotel sector in england. Canadian center of science and education: International journal of business and management. 10(3).

Kemenkes (2014). RISKESDAS. Jakarta: Balitbang Kemenkes RI.

Kusmayati L (2012). Faktor-faktor yang berhubungan dengan kinerja bidan dalam kunjungan $\mathrm{K} 4$ pada ibuhamil Di Puskesmas Syamtalira Bayu Kabupaten Aceh Utan Tahun 2012. Jurnal
Kesehatan Masyarakat: U'budiyah Banda Aceh.

Mangkunegara, Anwaar P (2011). Manajemen sumber daya manusia perusahaan. Bandung: PT. Remaja Rosdakarya.

Naharudin, Sadegi (2013). Factors of workplace environment that affectemployees performance: A casestudy of Miyazu Malaysia. International Journal of Independent Research and Studies, 2(2), 66-78.

PP IBI (2001). Bidan menyongsong masa depan, 50 tahun IBI. Jakarta: IBI.

Rivai V (2005). Performance appraisal. Jakarta: PT Raja GrafindoPersada.

Robbins, Stephen P, Coulter, Mary (2010). Manajemen (edisi kesepuluh). Jakarta: Erlangga.

Robbins, Stephen (2008). Perilaku organisasi, organizational behaviour. Jakarta: Gramedia.

Sarwono SW, Eko AM (2011). Psikologi sosial. Jakarta: Salemba Humanika.

Siswanto B (2002). Manajemen tenaga kerja Indonesia. pendekatan administratif dan operasional. Jakarta: Bumi Aksara.

Sondang SP (2001). Manajemen personalia dan sumber daya manusia. Jakarta: Rineka Cipta.

Sudirman (2003). Ilmu pendidikan. edisi I. Cetakan keenam. Bandung: Remaja Rosdakarya.

Sulistiyaningsih SH (2011). Faktor-faktor yang mempengaruhi kinerja bidan dalam deteksi kurang energy kronis ibu hamil di wilayah Kabupaten Pati.Tesis. Semarang: Universitas Diponegoro.

Wibowo (2010). Manajemen kinerja - edisi ketiga. Jakarta: PT. Raja Grafindo Persada 